\title{
Explicit-Reflective Teaching Nature of Science as Embedded within the Science Topic: Interactive Historical Vignettes Technique
}

\author{
Erdogan Melek Nur ${ }^{1}$, Koseoglu Fitnat ${ }^{2}$ \\ ${ }^{1}$ Ministry of Education, Yasemin Karakaya Science and Art Center, Ankara, Turkey \\ ${ }^{2}$ Gazi University, Chemical Education Department, Ankara, Turkey \\ Correspondence: Erdogan Melek Nur, Ministry of Education, Yasemin Karakaya Science and Art Center, Ankara, \\ Turkey
}

Received: July 27, 2015 Accepted: August 10, $2015 \quad$ Online Published: August 20, 2015

doi:10.11114/jets.v3i6.965 URL: http://dx.doi.org/10.11114/jets.v3i6.965

\begin{abstract}
It is obvious that more extensive work is needed in developing historical materials that address nature of science (NOS) concepts that will be implemented by teachers. Owing to the importance of meeting this need, research problem of this study is to design historical vignettes focused on the concept of chemical equilibrium which lies at the heart of high school and university chemistry topics by integrating NOS conceptions and to investigate whether the explicit-reflective teaching approach was effective in enhancing high school students' views of NOS. This study aims to examine the effects of nature of science instruction with interactive historical vignette on student conceptions of (NOS) and student development. Participants were a total of 17 eleventh grade students, 7 females $(41 \%)$ and 10 males (59\%), in public high school in Ankara, Turkey. Adopting qualitative research techniques, the study used open-ended questions to evaluate students' understandings of NOS and development, and reveal their accomplishments in the process. The results of this study indicate that the explicit-reflective approach to teaching of the chemical equilibrium unit to include NOS instruction as integrated within that content through interactive historical vignettes was effective in enhancing participant students' views of NOS.
\end{abstract}

Keywords: Nature of science; interactive historical vignette technique; chemical equilibrium teaching; high-school science

\section{Introduction}

Many science educators (Duschl, 1990; Hodson, 1998; Jenkins, 1996; Klopfer, 1969; Matthews, 1994) have long advocated the inclusion of the history of science in primary and secondary science teaching in order to prepare citizens who are scientifically literate. Nature of science (NOS) is an essential component in achieving scientific literacy (American Association for the Advancement of Science [AAAS], 1993; National Research Council [NRC], 1996). It is therefore important to identify the opinions of teachers and learners about the NOS and to develop effective instructional approaches that may improve their conceptions of it (Abd-El-Khalick \& Akerson, 2004; Aikenhead \& Ryan, 1992; Dogan, Cakıroglu, Bilican \& Cavusoglu, 2009; Köseoğlu, Tümay \& Budak, 2008; McComas \& Olson, 1998; Ryder, Leach, \& Driver, 1999; Schwartz, Lederman, \& Crawford 2000).

Abd-El-Khalick and Lederman (2000) claimed that failure of curricula and other research attempts, which they labeled as implicit, was due to the underlying assumption that students would learn NOS automatically as a result of studying science and engaging in inquiry activities. Thus, they argued that an understanding of NOS should be taken to be a cognitive learning outcome, which needs to be explicitly addressed and should be planned for instead of being anticipated as a side effect or secondary product. Moreover, many researchers (Abd-El-Khalick \& Lederman, 2000; Brickhouse, Dagher, Letts \& Shipman; Clough, 2006; Ryder, Leach, \& Driver, 1999) have suggested that explicit teaching of NOS within the content would lead to more improvement in students' views. Recent studies found that integrating the NOS with the contents of the science course by using the explicit-reflective approach improves the underdtanding of the NOS at all grade levels (Lederman, Abd-El-Khalick, Bell \& Schwartz, 2002; Lederman, 2007).

The literature has numerous studies showing that the history of science may be instrument in obtaining information about the NOS and the changes which have occurred in science over time, and other studies that encourage the use of historical examples of science to teach its nature (Abd-El-Khalick, 1999; Clough \& Olson, 2004; Irw1n, 2000; Matthews, 
1994; Solomon, Scott \& Duveen, 1996; Stinner, McMillan, Metz, Jilek \& Klassen, 2003). Wandersee and Roach (1998) proposed the use of interactive historical vignette (IHV) to prevent the weakness of decontextualization and their method has evidently been effective in improving the students' understanding of the nature of science. IHV technique can catch students in the classroom with histories of interesting people and events (Clary \& Wandersee, 2006). Roach and Wandersee (1995) write that vignettes should be historically accurate but details may be fictionalized.

It is obvious that more extensive work is needed in developing historical materials that address NOS concepts that will be implemented by teachers. Owing to the importance of meeting this need, this study aims to design historical vignettes focused on the concept of chemical equilibrium which lies at the heart of high school and university chemistry topics by integrating NOS conceptions and to investigate whether the explicit-reflective teaching approach was effective in enhancing high school students' views of NOS. In addition, the emergence of the concept of chemical equilibrium was shown to students, a discussion was initiated in the classroom to give students questions to study later, and instructional environments to get them interested in new scientific inventions were established.

The present study taught nature of science conceptions integrated into the topic of chemical equilibrium by using IHV and focusing on the historical development of concepts related to chemical equilibrium. With discussions held in the process, students' attention was drawn to their conceptions of NOS and maximum effort was made to ensure that students actively participated in the discussions. In this way, students could contemplate, discuss and explain their own conceptions of NOS by using the NOS conceptions given in the vignettes containing snapshots of scientists' lives as an explicit component of class discussions.

\section{Method}

Participants were a total of 17 eleventh grade students, 7 females (41\%) and 10 males (59\%), in public high school in Ankara with a low to middle socio-economic status. Participants were instructed by the their regular classroom science teacher (first author). The treatment spanned 4 weeks, which participants were instructed about NOS and some of the key ideas of chemical equilibrium for three 45 -minute sessions per week as part of their regular science lessons.

\subsection{Context of the Study: A Unit of Science Content and NOS with IHV Technique}

The study considered the design of teaching of the chemical equilibrium unit to include NOS instruction as integrated within that content through interactive historical vignettes. Seven aspects of NOS (tentativeness, empirical, subjectivity, creativity, socio-cultural values, observation and inference, theory and law) were targeted since the authors believe that those could be teach easily by integrating within the chemical equilibrium unit. Two IHV(s) about the historical development of the concept of chemical equilibrium were designed in line with the conceptual change approach. The basic structures of the vignettes were based on the outline given by Roach and Wandersee (1993, 1995). The introductory part of vignettes included a problem or conflict about the topic of chemical equilibrium so that the students' interest would be ensured and make them think. Then, important events and actions in the life stories of scientists who contributed to the emergence of the concept of chemical equilibrium were given in the text. Questions that are likely to start class discussions were inserted in certain points of the vignettes and their answers were sought. Thus, students found themselves in a conflict by comparing old and new information. Towards the end of the vignettes, the conflicts were resolved thus enabling students to grasp the historical development of the concepts. Care was taken to ensure that the vignettes included reflective discussion questions about the NOS, suggesting that phenomena can be understood through science, scientific ideas are resistant at the face of change, and science cannot answer all questions.

\subsubsection{Vignette-1: Competing Theories}

The vignette designed in sketch form was about two important key ideas of chemical equilibrium, "Theory of Chemical Affinity" and "Law of Mass Action". The story tells that Bergman explained the formation of chemical elective by referring to chemical affinity, but also added that there are certain reactions that do not comply with the rule, and that he could not explain these, while Berthollet stated that the formation of chemical reactions depend on the amount of the substances in reaction, this is valid for all reactions, and he reached the concept of chemical equilibrium as a result of an incidental observation while studying this topic.

The first part of the Competing Theories vignette given in Figure-1 was distributed to students for individual reading and pair discussion. Later, the teacher asked the whole class some questions such as "How do Bergman and Berthollet explain the formation of chemical reactions?" and "What does chemical affinity mean to you?", and a class discussion was held. 


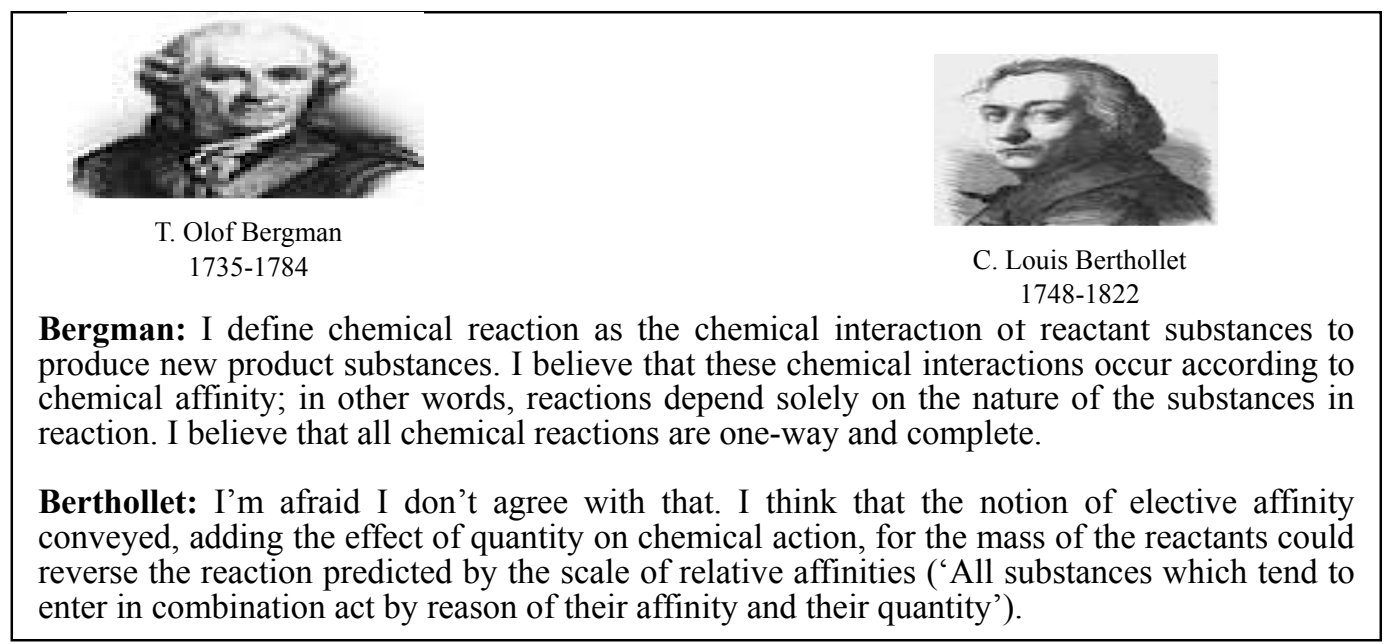

Figure 1. The first part of Vignette-1 distributed to students.

Below are sample responses from several students during this discussion:

“....For me, chemical affinity is the tendency of atoms to become decisive by receiving or releasing electrons. Of course it is now very easy to explain this. It's interesting that these were considered in those times...."

“....it must be something such as electron knowledge...Had electrons been defined by then?...

Upon this, the teacher reminded the class of the atom models that they studied in 9th grade and the first atom model was proposed in the 1800's by Dalton and the concept of electron in the late 1800's by Thomson. Thus, the teacher ensured that the concepts of "chemical affinity" were made an interesting topic of discussion.
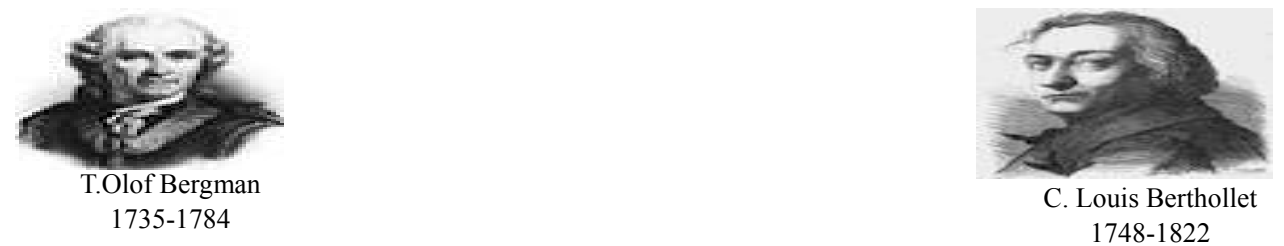

Bergman: I developed a table based on the chemical properties and appearance of substances. Based on this tabie, I believed that chemical combinations were the result of the 'elective affinities', which solely depended on the nature of the chemicals involved in their action. I considered that all chemical reactions were complete and took place in one direction. In spite of some anomalous reactions, I felt that those anomalies resulted form inadequate data believing that further and careful experimentation would enable chemists to fit all reactions into ordered displacement affinity series without inconsistencies.

Berthollet: If you allow me, I'll tell you about an observation of mine. I accompanied our king Napoleon on a trip to Egypt in 1798. When I was there, I observed continuous $\mathrm{Na}_{2} \mathrm{CO}_{3}$ formation in rocks surrounding sodium lakes. This interested me and $\mathrm{I}$ defined this reaction as follows upon studying it:

$\mathrm{CaCO}_{3}+2 \mathrm{NaCl} \rightarrow \mathrm{CaCl}_{2}+\mathrm{Na}_{2} \mathrm{CO}_{3}$

However, this reaction was the reverse of that predicted by the theory of elective affinities. I was amazed because the theory claims that there action will be:

$\mathrm{CaCl}_{2}+\mathrm{Na}_{2} \mathrm{CO}_{3} \rightarrow \mathrm{CaCO}_{3}+2 \mathrm{NaCl}$.

I observed that even though $\mathrm{CaCl}_{2}$ (calcium chloride) and $\mathrm{Na}_{2} \mathrm{CO}_{3}$ (sodium carbonate) were supposed to have run out completely, both abounded in the environment, and the sodium carbonate formed a crust around the edge of the lake, and the deliquescent calcium chloride seeped into the ground. This finding delighted me because my observation had shed light on the questions whose answer I had been seeking. I thus objected to the perception that elective affinity was an absolute, constant force that always determined the outcome of displacement reactions, and I thought that the effect of quantity on chemical action, for the mass of the reactants could reverse the reaction predicted by the scale of relative affinities.

Bergman: Rather interesting. I had defined some reactions against the theory of chemical affinity as abnormal reactions. Well, can you explain these abnormal reactions with this finding of yours?

Berthollet: Yes, these abnormal reactions are incomplete and reversible reactions. As a result of the experiments I conducted upon returning from Egypt, even though I cannot explain it mathematically, I can say any displacement reaction was never complete but that there was an equilibrium state between opposite affinity forces. The strength of these forces, therefore, depended on two factors: the difference in their relative affinities and the quantitative proportion, "All

Figure 2. The second part of Vignette-1 distributed to students. 
After defining the concept of chemical affinity, small group and class discussions were held to seek answers to the question "Do you agree with Bergman that all chemical reactions are completed and took place in one direction? As students had always thought about reactions as one-way until that time, a dilemma was raised with this question and, the teacher distributed the second part of the story shown in Figure-2 without answering the questions directly. The students were asked to read this part individually and discuss it in pairs.

Later, a whole class discussion was held with the teacher's guidance through some questions such as following:

- Does Berthollet support the theory of chemical affinity in the formation of chemical reactions? Or does he refute it? What are his reasons?

- How did the concept of reversibility in chemical reactions appear? What stages of the scientific method were used by the Berthollet?

- Does imagination and creativity have a place in Berthollet's observation? If yes, in what stage?

The students were asked to construct and share their own opinions about the two scientists' theories, hypotheses, data and inferences about the formation of chemical reaction. The discussion led to the conclusion that Berthollett did not fully refute Bergman's theory but improved it, thus enabling students to understand how a scientific piece of information about the concept of chemical equilibrium emerged and in what way this knowledge was obtained. In this process through the explicit-reflective discussions, the students' understandings of the aspects of NOS such as the tentative of scientific knowledge, the difference between observation and inference, the role of imagination and creativity in the formation of scientific knowledge were made efforts to develope.

\subsubsection{Vignette-2: The First Mathematical Formulation of Chemical Equilibrium}

The second vignette was inspired by scientific historical studies (Quilez, 2007) that revealed the first mathematical formulation of the concept of chemical equilibrium. Including the studies of Guldberg and Waage, the vignette titled "The Mathematical Formulation of Chemical Equilibrium" was also given to students in two pieces. The first part of the story (Figure-3) was distributed to students to be read individually, to be followed by a pair discussion on the question that Guldberg and Waage were studying and why they felt the need to do so. After the discussions, students were guided to the conclusion that Guldberg and Waage were trying to find a mathematical equation that showed the results of experimental data.

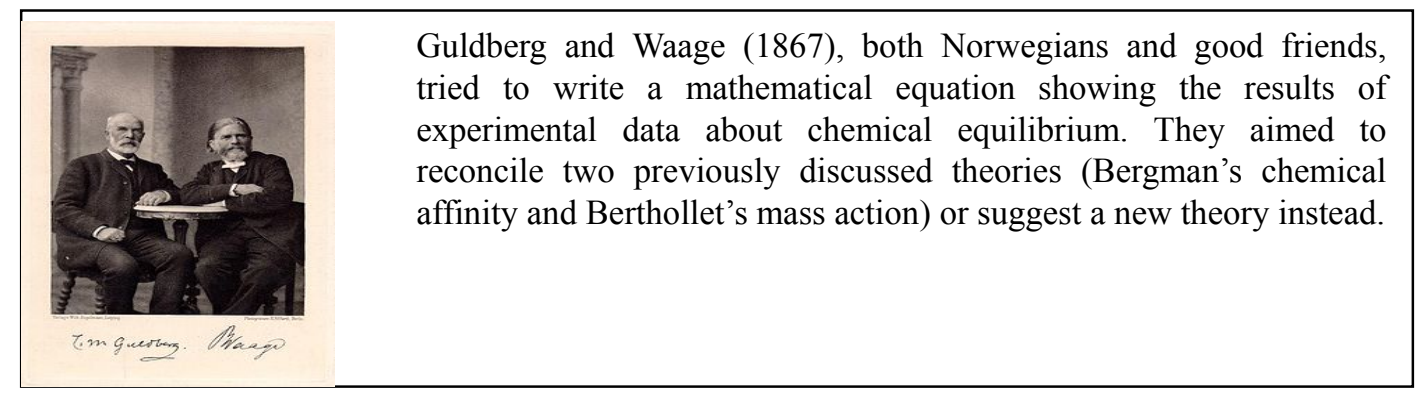

Figure 3. The first part of Vignette-2 distributed to students.

Then, the second part of the vignette (Figure-4), was distributed to students for individual reading and a pair discussion followed this. A whole class discussion with the guidance of the teacher was held by targeting to develop the understandings of students about concepts of scientific theory and laws and theory-laden through some questions, some of them are followed:

- What paradigm Guldberg and Waage did take into account to reach a quantitative expression?

- Why are mathematical equations needed to explain a chemical reaction? What benefits do they have?

- Did Guldberg and Waage make use of previous theories on the topic while reaching this equation? If yes, how?

Later, in the process of teaching the equilibrium constant, the key concept of chemical equilbrium topic, the students were divided into groups and asked them to discuss and try to derive a mathemetical equation for equilibrium constant by using Guldberg and Waage's explanations and algorithmic methods on the question given at the end of the second part of the vignette (Figure 4).

A class discussion was also held with the students on how the two scientists worked together and whether Guldberg's previous work about mathematic and experiences had any effect on the present study about chemical equilibrium. This was done to emphasize that scientists' prior knowledge, personal backgrounds, and other "human" elements influenced 
how they interpreted data. Thus, the students were enabled to reach informed views of targeted NOS aspects about science is a complex social activity and scientific knowledge is subjective.

Guldberg and Waage considered mechanics as the paradigm and focused on
what the forces they named "chemical forces" were and how they could
measure them. As in mechanics, Guldberg and Waage argued that chemistry
should also be a science involving forces and their effects, and they stated
their views during that period as follows:
"In beginning our studies in 1861, we thought it might be possible to find numerical values for the
magnitudes of chemical forces. We also thought that we might find for each element and for each
chemical compound certain numbers which would express their relative affinities, as atomic weights
express their relative weights (Guldberg\&Waage 1867 , p. 74 . cited in; Quilez, 2007). They explained
their studies as follows:
"We believe that according to the Law of Mass Action, the speed of chemical reactions is the
proportion with which the effective mass of substances in reaction transform into products. If we wish
to show the effective mass of a substance, we may do so by writing the chemical formula of the
substance in brackets. For instance, we may use [HCl] for hydrochloride. In light of ourstudies, we
derived the balance constant by using kinetic data and speed equations. We are of the opinion that
balance is possible when the driving forces of forward and reverse reactions are equal. Now let's
explain the Mass Law Action with an example:
A $+\mathrm{B} \leftrightarrow \mathrm{X}+\mathrm{Y}$
The driving factor of forward reaction $\alpha[\mathrm{A}][\mathrm{B}]$
( $\alpha$ : Direct proportion sign)
$\mathrm{K}_{\mathrm{i}}$ is the rate constant of forward reaction.
Similarly, the driving factor of reverse reaction $\alpha[\mathrm{X}][\mathrm{Y}]$
$+\mathrm{yY}$ reaction with mathematical equations by using the explanations and equations above and try to
reach the $\mathrm{K}$ equilibrium constant by using Guldberg and Waage's explanations.
$=\mathrm{K}_{\mathrm{i}}[\mathrm{A}][\mathrm{B}]$

Figure 4. The second part of Vignette-2 distributed to students.

\subsection{Data Collection and Evaluation}

In order to evaluate high school students' aspects of the NOS before and after instruction, the Views on the Nature of Science Questionnaire- FORM-C (VNOS-C) designed by Lederman et al. (2002) was used. Having 10 open-ended questions, the pre and post VNOS-C questionnaires were analyzed by both researchers, as suggested by Lederman, Khalick, Bell and Schwartz (2002). For data analysis, systematic approach parallel to the framework used by Khishfe \& Lederman (2006) was conducted by two independent researchers. The participants' responses were categorized as naive, transitional and informed ideas for each of seven nature of science aspects. Each student was coded as S1, S2 ........S17, their responses to the VNOS-C were examined, and a summary profile was established to reveal their aspects of NOS. Each aspect was scored with a "-" to indicate the response was naive, "++" for the student's abilities to articulate the meaning of the aspect in his/her own words, or a "+++" to indicate the students' abilities to articulate the meaning of the aspect in his/her own words and provide examples in addition to those discussed in the instruction on the NOS. The post-instruction NOS profiles were generated via the same procedure, utilizing the post VNOS-C questionnaires. Each 
“+” was assigned a value of one and each "-“had a value of zero $(0)$. Then all pluses $(+)$ were added to get a total score for each students and for each aspect of the NOS. The researchers discussed and compared results to smooth any possible differences that might rise at the end of content analysis. Finally, the rate of conscious views in the NOS conceptions of each student was calculated. The agreement between the two researchers' scores was calculated (Chiappetta, Sethna, and Fillman, 1991). The scores given by the two raters for each pre and post questionnaire, agreement rate percentages, and Kappa values are given in Table-1 and Table- 2.

Table 1. Student's Pre-instruction Profiles of the NOS.

\begin{tabular}{|c|c|c|c|c|c|c|c|c|c|c|}
\hline 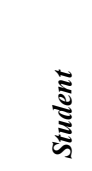 & 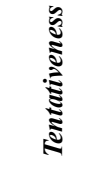 & ב气 & 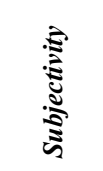 & ثิ & 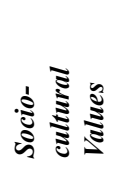 & 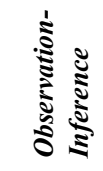 & डेँ & 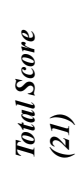 & 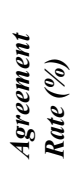 & 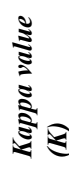 \\
\hline S1 & + & +++ & - & +++ & - & - & - & 7 & 85,7 &, 83 \\
\hline S2 & ++ & ++ & + & +++ & - & + & - & 9 & 88,8 &, 92 \\
\hline S3 & + & ++ & ++ & ++ & - & + & + & 9 & 77,7 &, 71 \\
\hline S4 & + & + & - & +++ & + & + & + & 8 & 87,5 &, 86 \\
\hline S5 & + & - & + & +++ & ++ & + & + & 9 & 88,8 &, 87 \\
\hline S6 & ++ & ++ & - & + & + & + & + & 8 & 87,5 &, 86 \\
\hline S7 & + & + & + & - & ++ & ++ & + & 8 & 87,5 & 86 \\
\hline S8 & + & +++ & ++ & +++ & - & + & - & 10 & 80,0 &, 75 \\
\hline S9 & + & ++ & + & ++ & ++ & + & + & 10 & 80,0 &, 75 \\
\hline $\mathrm{S} 10$ & + & + & - & ++ & + & + & + & 7 & 85,7 &, 83 \\
\hline S11 & ++ & ++ & + & ++ & - & + & - & 8 & 87,5 &, 86 \\
\hline $\mathrm{S} 12$ & + & + & - & + & + & + & + & 6 & 83,3 &, 79 \\
\hline $\mathrm{S} 13$ & ++ & ++ & ++ & ++ & ++ & ++ & + & 13 & 88,8 &, 87 \\
\hline S14 & ++ & ++ & + & + & +++ & ++ & ++ & 14 & 72,7 &, 62 \\
\hline S15 & + & + & + & ++ & ++ & ++ & ++ & 11 & 83,3 &, 79 \\
\hline S16 & + & ++ & + & ++ & + & + & + & 9 & 88,8 &, 87 \\
\hline S17 & ++ & + & + & ++ & ++ & ++ & + & 10 & 80,0 &, 75 \\
\hline $\begin{array}{l}\text { Total } \\
\text { (51) }\end{array}$ & $\begin{array}{c}23 \\
(45 \%)\end{array}$ & $\begin{array}{c}28 \\
(55 \%)\end{array}$ & $\begin{array}{c}15 \\
(29 \%)\end{array}$ & $\begin{array}{c}34 \\
(67 \%)\end{array}$ & $\begin{array}{c}20 \\
(39 \%)\end{array}$ & $\begin{array}{c}21 \\
(41 \%)\end{array}$ & $\begin{array}{l}15 \\
(29 \\
\%) \\
\end{array}$ & & & \\
\hline Mean & & & & & & & & $\begin{array}{c}9,2 \\
(44 \%)\end{array}$ & 84,3 & ,81 \\
\hline
\end{tabular}

Table 2. Student's Post-instruction Profiles of the NOS.

\begin{tabular}{|c|c|c|c|c|c|c|c|c|c|c|}
\hline Е & 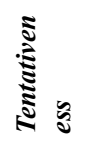 & בัป & 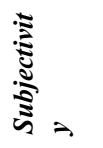 & ड़े & 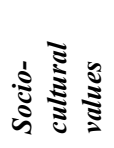 & 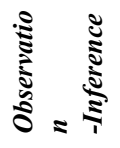 & $\begin{array}{l}\text { हैं } \\
\text { है }\end{array}$ & 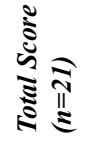 & 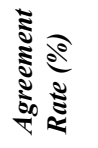 & 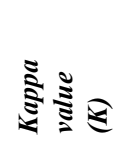 \\
\hline S1 & ++ & +++ & ++ & +++ & ++ & ++ & + & 15 & 72,5 & ,62 \\
\hline S2 & +++ & ++ & ++ & +++ & ++ & ++ & ++ & 16 & 88,8 &, 85 \\
\hline S3 & +++ & ++ & +++ & +++ & +++ & ++ & ++ & 18 & 80,1 &, 75 \\
\hline S4 & ++ & +++ & + & +++ & +++ & + & - & 13 & 87,5 &, 86 \\
\hline S5 & ++++ & +++ & ++++ & ++++ & +++ & +++ & ++ & 20 & 85,2 &, 83 \\
\hline S6 & ++ & +++ & ++ & +++ & + & ++ & + & 14 & 80,1 &, 75 \\
\hline S7 & +++ & ++ & ++ & ++ & ++ & ++ & + & 14 & 66,6 &, 50 \\
\hline S8 & +++ & +++ & +++ & +++ & + & + & +++ & 17 & 80,0 &, 75 \\
\hline S9 & ++ & +++ & ++ & +++ & ++ & ++ & + & 15 & 80,0 &, 75 \\
\hline S10 & + & ++ & + & ++ & ++ & ++ & + & 11 & 85,2 &, 83 \\
\hline S11 & +++ & +++ & ++ & +++ & + & + & ++ & 15 & 87,5 &, 86 \\
\hline S12 & ++ & ++ & - & ++ & - & + & + & 8 & 83,3 & ,79 \\
\hline S13 & ++ & + & ++ & +++ & +++ & +++ & + & 15 & 84,5 &, 83 \\
\hline S14 & +++ & ++ & ++ & ++ & +++ & ++ & ++ & 16 & 90,2 & ,89 \\
\hline S15 & + & + & + & +++ & +++ & ++ & ++ & 13 & 83,3 &, 79 \\
\hline S16 & ++ & +++ & + & ++++ & ++ & ++ & ++ & 15 & 85,2 & 83 \\
\hline S17 & +++ & ++ & ++ & +++ & +++ & ++ & + & 16 & 84,5 &, 83 \\
\hline $\begin{array}{l}\text { Total } \\
(51)\end{array}$ & $\begin{array}{c}40 \\
(78 \%)\end{array}$ & $\begin{array}{c}40 \\
(78 \%)\end{array}$ & $\begin{array}{c}31 \\
(61 \%)\end{array}$ & $\begin{array}{c}46 \\
(90 \%)\end{array}$ & $\begin{array}{c}35 \\
(69 \%)\end{array}$ & $\begin{array}{c}32 \\
(63 \%)\end{array}$ & $\begin{array}{l}25 \\
(49 \\
\%) \\
\end{array}$ & & & \\
\hline Mean & & & & & & & & $\begin{array}{l}14,8 \\
(70 \%) \\
\end{array}$ & 82,6 & ,78 \\
\hline
\end{tabular}




\section{Results}

Table-1 shows that most students did not have informed views of the NOS before the instruction. The highest total score $(34 ; 67 \%)$ was in the creativity dimension, and the lowest one $(15 ; 29 \%)$ in the subjectivity and theory/law dimensions. Students' mean score was 9,2 (44\%), mean agreement rate between the two researchers 84,3\%, and Kappa value .81.

Table-2 shows that most students improved their understanding about the NOS by the end of the study. The highest score $(46 ; 90 \%)$ was in the creativity dimension, while the lowest score $(25 ; 49 \%)$ was in the theory/law dimension. Students' mean score was 14,8 (70\%), mean agreement rate between the two researchers 82,6 \%, and Kappa value .78.

\subsection{Student Views on the NOS}

After the analysis of the pre and post questionnaires, a relative value was assigned to each students and the assignment was based on how much the student(s) elaborated on the responses in the questionnaires.

Finally, participants' profiles, which were categorized into naive, transitional, and informed, to assess changes in participants' views for each of the seven NOS aspects. Students' performances on the NOS have been presented below in Table 3. The data shows that before instruction, only one student $(5,9 \%)$ had an "informed" view of NOS; two $(11,8 \%)$ had "transitional" views; and all others $(82,3 \%)$ had "naive" views. At the end of the instruction, twelve students $(70,6 \%)$ had "informed" views of NOS, four $(23,5 \%)$ had "transitional" views, and one $(5,9 \%)$ had a "naive" view.

Table 3. Students' Pre-Post Performans on the NOS.

\begin{tabular}{lcccl}
\hline Name & $\begin{array}{c}\text { Pre-test } \\
(\mathrm{n}=21)\end{array}$ & Relative value & $\begin{array}{c}\text { Post-test } \\
(\mathrm{n}=21)\end{array}$ & Relative value \\
\hline S1 & $7(33 \%)$ & naive & $15(71 \%)$ & informed \\
S2 & $9(43 \%)$ & naive & $16(76 \%)$ & informed \\
S3 & $9(43 \%)$ & naive & $18(86 \%)$ & informed \\
S4 & $8(38 \%)$ & naive & $13(62 \%)$ & transitional \\
S5 & $9(43 \%)$ & naive & $20(95 \%)$ & informed \\
S6 & $8(38 \%)$ & naive & $14(67 \%)$ & transitional \\
S7 & $9(43 \%)$ & naive & $14(67 \%)$ & informed \\
S8 & $10(48 \%)$ & naive & $17(81 \%)$ & informed \\
S9 & $10(48 \%)$ & naive & $15(71 \%)$ & informed \\
S10 & $7(33 \%)$ & naive & $11(52 \%)$ & transitional \\
S11 & $8(38 \%)$ & naive & $15(71 \%)$ & informed \\
S12 & $6(29 \%)$ & naive & $8(38 \%)$ & naive \\
S13 & $13(62 \%)$ & transitional & $15(71 \%)$ & informed \\
S14 & $14(67 \%)$ & informed & $16(76 \%)$ & informed \\
S15 & $11(52 \%)$ & transitional & $13(62 \%)$ & transitional \\
S16 & $9(43 \%)$ & naive & $16(76 \%)$ & informed \\
S17 & $10(48 \%)$ & naive & $16(76 \%)$ & informed \\
Mean Score & 9,2 & naive & 14,8 & informed \\
& $(44 \%)$ & & $(70 \%)$ & \\
\hline
\end{tabular}

The result of the study reveals that the majority of students made significant progress in their personal conceptions of nature of science through instruction. The mean total scores of all students in all aspects of NOS before instruction was 9,2 (44\%), which increased to $14,8(70 \%)$ at the end of instruction. There was a significant improvement in the participants' views of the NOS in the post-instruction assessment, as a evidenced in the rise of the group average score. Moreover, at the end of instruction, most students were found to have a conscious conception of NOS and refer to the vignettes on chemical equilibrium in their explanations and examples. Thus, it may be argued that the IHV technique used in this study was useful in improving students' NOS conceptions.

\subsection{Change in Views of the Various Dimension of NOS}

After scoring individual student's responses on each targeted aspect of the NOS, a sum of the points for each aspect was calculated. Each aspect was worth 3 points. Table 4 shows the scores for about their NOS conceptions, the total score for each targeted aspect of the NOS before and after the instruction. Note that the aspects of the NOS are listed in the order of post-instruction scores.

Prior to instruction, the majority of students had a "informed" understanding of the role of imagination and creativity in science, a "transitional" understanding in the empirical dimension, and a "naive" understanding in others. At the end of the instruction, the most significant change occurred in students' understanding of the tentative of scientific knowledge. This could be result of content of the vignettes provided a lot of occasions to discuss the tentativeness of scientific knowledge. Thus, having seen that the knowledge produced by scientists can change over time, the students emphasized 
this in their responses to the questionnaire items and explained the change in scientific knowledge by giving examples from the vignettes. In addition, significant improvement was also seen in the understandings of the participants about the role of subjectivity in scientific studies and the effects of social, cultural values on science. However, they maintained their "naive" conceptions of the functions and relationships between scientific theory and laws at the end of instruction.

Table 4. Class Performance on the Aspects of the NOS.

\section{Discussion}

\begin{tabular}{lccc}
\hline Aspect of the NOS & $\begin{array}{c}\text { Pre-instruction } \\
(\mathbf{n = 5 1 )}\end{array}$ & $\begin{array}{c}\text { Post-instruction } \\
(\mathbf{n = 5 1 )}\end{array}$ & $\begin{array}{c}\Delta \\
\text { (Change) }\end{array}$ \\
\hline Creativity & $34(67 \%)$ & $46(90 \%)$ & $12(23 \%)$ \\
Empirical & $28(55 \%)$ & $40(78 \%)$ & $12(23 \%)$ \\
Tentativeness & $23(45 \%)$ & $40(78 \%)$ & $17(33 \%)$ \\
Observation-Inferenc & $21(41 \%)$ & $32(63 \%)$ & $11(22 \%)$ \\
Socio-cultural Values & $20(39 \%)$ & $35(69 \%)$ & $15(30 \%)$ \\
Subjectivity & $15(29 \%)$ & $31(61 \%)$ & $16(32 \%)$ \\
Theory/Law & $15(29 \%)$ & $25(49 \%)$ & $10(20 \%)$ \\
\hline
\end{tabular}

In the study, NOS conceptions were integrated into the topic of chemical equilibrium and used the explicit-reflective approach. The historical vignettes used in the study were designed to provide contemplation and discussion opportunities on NOS aspects, particularly aspects of tentativeness, empirical, theory-laden, being a product of human imagination, creativity and interpretation, and socio-cultural values of scientific knowledge. The vignettes used were focused on the historical development of key concepts related to chemical equilibrium and they intended to trigger in students a positive attitude towards science by showing them the research and contribution of scientists. With discussions held in the process, students' attention was drawn to their conceptions of NOS and maximum effort was made to ensure that students actively participated in the discussions. In this way, students could contemplate, discuss and explain their own conceptions of NOS by using the information in the story given in the vignettes.

The results of this study indicate that the explicit-reflective approach to NOS instruction within a science topic, chemical equilibrium, through the interactive historical vignettes technique was effective in enhancing high school students' views of NOS. At the outset of the present study, a majority of participants $(82,3 \%)$ held naive views of the NOS aspects. These findings are consistent with previous studies which evaluated the NOS conceptions of students (BouJaoude, 1996; Doğan \& Özcan, 2010; Khishfe \& Abd-El-Khalick, 2002; Smith, Maclin, Houghton \& Hennessey, 2000; Meichtry, 1992). As seen from the data in the Table 4, analysis of the findings of the study showed an overall positive change in student conceptions of the dimensions of NOS included in this study. Although the teaching approach used in the study might have positively improved students' NOS conceptions in general, the improvement was not the same in all dimensions of nature of science. Especially, "theory and law" seems to be the dimension hardest to understand for participants, which may result from the fact that myths about these concepts had been taught in formal education until recent years. Thus, almost all participants explicated inadequate views about the relationship between theories and laws prior to instruction. At the end of the study, the students were also not successful in their statements about scientific theories/laws and particularly in their examples, thus failing to demonstrate a significant improvement. This may result from that relationships of scientific theories and laws were not directly mentioned in the vignettes used.

This study suggests that teaching the nature of science through a historical approach is an effective and promising strategy that can also be applied inside the classrooms. Historical case studies can also inspire and motivate teachers and students by helping them to share the experience and excitement of early scientists in the process of creating scientific knowledge.

\section{References}

Abd-El-Khalick, F. (1999). Teaching science with history. The Science Teacher, 66(9), 18-22.

Abd-El-Khalick, F. S., \& Akerson, V. L. (2004). Learning about nature of science as conceptual change: Factors that mediate the development of preservice elementary teachers' views of nature of science. Science Education, 88 , 785-810. http://dx.doi.org/10.1002/sce.10143

Abd-El-Khalick, F., \& Lederman, N. G. (2000). The influence of history of science courses on students' views of nature of science. Journal of Research in Science Teaching, 37(10), 1057-1095. http://dx.doi.org/10.1002/1098-2736(200012)37:10<1057::AID-TEA3>3.0.CO;2-C

Aikenhead, S. G., \& Ryan, G. A. (1992). The development of a new instrument: "Views on science- technology- society" (VOSTS). Science Education, 76(5), 477-491. http://dx.doi.org/10.1002/sce.3730760503

American Association for the Advancement of Science (1993). Benchmarks for science literacy: Project 2061. New 
York: Oxford University Press. http://www.project2061.org/publications/bsl/online/index.php

BouJaoude, S. (1996). Why an issue on science education? (Editorial). Scie-Quest, 6(1), 4-5.

Brickhouse, N. W., Dagher, Z. R., Letts, W. J., \& Shipman, H. L. ( 2000). Diversity of Students "e Views About Evidence, Theory, and the Interface Between Science and Religion in an Astronomy Course". Journal of Research in Science Teaching 340-362. http://dx.doi.org/10.1002/(SICI)1098-2736(200004)37:4<340::AID-TEA4>3.0.CO;2-D

Chiappetta, E. L., Sethna, G. H., \& Fillman, D. A. (1991). A quantitative analysis of high school chemistry textbooks form scientific literacy themes and expository learning aids. Journal of Research in Science Teaching, 28(10), 939-951.

Clarly, M. R.. \& Wandersee J. H. (2006). Mary Anning: She's more than "Seller of sea shells at the seashore". The American Biology $\quad$ Teacher, 68(3), 153-158. http://dx.doi.org/10.1662/0002-7685(2006)68[153:MASMTS]2.0.CO;2

Clough, M. P. (2006). Learners' responses to the demands of conceptual change: Considerations for effective nature of science instruction. Science \& Education, 15(5), 463-494. http://dx.doi.org/10.1007/s11191-005-4846-7

Clough, M. P., \& Olson, J. K. (2004). The nature of science: Always part of the science story. The Science Teacher, 71(9), 28-31.

Clough, M. P., \& Olson, J. K. (2004). The nature of science: Always part of the science story. The Science Teacher, 71(9), 28-31.

Doğan, N., \& Özcan M., B. (2010). Tarihsel yaklaşımın 7. sınıf öğrencilerinin bilimin doğası hakkındaki görüşlerinin geliştirmesine etkisi. Ahi Evran Ün., Kırşsehir Eğitim Fak. Dergisi, 11(4), 187-208.

Doğan, N., Çakıroğlu, J., Bilican, K., \& Çavuş, S. (2009). Bilimin doğası ve öğretimi. Ankara: Pegem Akademi Yayıncilik.

Driver, R., Leach, J., Millar, R., \& Scott, P. (1996). Young people's images of science. Buckingham: Open University Press.

Duschl, R. A. (1990). Restructuring science education: The importance of theories and their development. Teachers College Press, Columbia University, New York.

Hodson, D. (1988) Toward a philosophically more valid science curriculum. Science Education, 72(1), 19- 40. http://dx.doi.org/10.1002/sce.3730720103

Irwin, A. R., (2000). Historical case studies: Teaching the nature of science in context. Science Education, 84(1), 5-26. http://dx.doi.org/10.1002/(SICI)1098-237X(200001)84:1<5::AID-SCE2>3.0.CO;2-0

Jenkins, E. W. (1996) The 'Nature of Science' as a curriculum component. Journal of Curriculum Studies, 28(3), 137-150. http://dx.doi.org/10.1080/0022027980280202

Khishfe, R. F., \& ve Abd-El-Khalick, F. S. (2002). Influence of explicit and reflective versus implicit inquiry-oriented instruction on sixth graders"e views of nature of science. Journal of Research in Science Teaching, 39, 551-578. http://dx.doi.org/10.1002/tea.10036

Klopfer, L. E. (1969). The teaching of science and the history of science. Journal of Research in Science Teaching, 6, 87-97. http://dx.doi.org/10.1002/tea.3660060116

Köseoğlu, F., Tümay, H., \& Budak E., (2008). Paradigm Changes about Nature of Science and New Teaching Aproaches. Gazi Egitim Fakultesi Dergisi, 28(2), 221-237.

Lederman, N. G. (2007). Nature of science: Past, present, and future. In Abell, S. \& Lederman, N. (Eds.) Handbook of Research on Science Education. Mahwah, New Jersey: Lawrence Erlbaum Associates, Publishers.

Lederman, N. G., Abd-El-Khalick, F., Bell, R. L., \& Schwartz, R. S. (2002). Views of nature of science questionnaire (VNOS): Toward valid and meaningful assessment of learners' conceptions of nature of science. Journal of Research in Science Teaching, 39(6), 497-521. http://dx.doi.org/10.1002/tea.10034

Matthews, M. R. (1994). Science teaching: The role of history and philosophy of science, Routledge, New York.

McComas, W. F., \& Olson, J. K. (1998). The nature of science in international science education standards documents. In McComas, W. F. (Ed.), The nature of science in science education: Rationales and strategies (pp. 41-52), Kluwer Academic Publisher.

Meichtry, Y. J. (1992). Influencing student understanding of the nature of science: Data from a case of curriculum 
development. Journal of Research in Science Teaching, 29, 389-407. http://dx.doi.org/10.1002/tea.3660290407

National Research Council (NRC). (1996). National Science Education Standards. Washington, DC: National Academy Press.

Ouilez, J. (2007). A historical/philosophical foundation for teaching chemical equilibrium. $9^{\text {th }}$ International History Philosophy \& Science Teaching Conference, Calgary /Canada.

Roach, L. E., \& Wandersee, J. H. ( 1995). Putting people back into science: Using historical vignettes. School Science and Mathematics, 95(7), 365-370. http://dx.doi.org/10.1111/j.1949-8594.1995.tb15802.x

Roach, L., \& Wandersee, J. H. (1993). Short story science. The Science Teacher, 60(6), 18-21.

Ryder, J., Leach, J., \& Driver, R. (1999). Undergraduate science students' images of science. Journal of Research in Science $\quad$ Education, 201-219. http://dx.doi.org/10.1002/(sici)1098-2736(199902)36:2<201::aid-tea6>3.0.co;2-h

Schwartz, R., Lederman, N. G., \& Crawford, B. A. (2000). Making connections between the nature of science and scientific inquiry: A science research internship for pre-service teachers. Paper presented at the annual meeting of Association for the Education of Teachers in Science, Akron, $\mathrm{OH}$.

Smith, C. L., Maclin, D., Houghton, C., \& Hennessey, M. G. (2000). Sixth-grade students' epistemologies of science: The impact of school science experiences on epistemological development. Cognition and Instruction, 18(3), 349-422. http://dx.doi.org/10.1207/S1532690XCI1803_3

Solomon, J., Scott, L., \& Duveen, J. (1996). Large Scale Exploration of Pupils' Understanding of the Nature of Science. Science $\quad$ Education $\quad 80, \quad 493-508$. http://dx.doi.org/10.1002/(SICI)1098-237X(199609)80:5<493::AID-SCE1>3.0.CO;2-6

Stinner, A., McMillan, B. A., Metz, D., Jilek, J. M., \& Klassen, S. (2003). The renewal of case studies in science education. Science and Education, 12, 617-643. http://dx.doi.org/10.1023/A:1025648616350

Wandersee J. H., \& Roach L. M. (1998). Interactive historical vignettes. J. J. Mintzes, J. H. Wandersee, and J. D. Novak (ed.) Teaching science for understanding: a human constructivist view (pp. 281-306). San Diego, CA, USA: Academic Press.

\section{$(\mathrm{cc}) \mathrm{Br}$}

This work is licensed under a Creative Commons Attribution 3.0 License. 